\title{
HIV Test and Antiretroviral Treatment for Pregnant Women in Kota Kupang and Yayasan Bumi Sehat Ubud
}

\author{
Luxi Riajuni Pasaribu ${ }^{1 *}$, Rachmalina Prasodjo ${ }^{1}$, Felly Philipus Senewe ${ }^{1}$, \\ Lilian Susanti Nova ${ }^{1}$
}

${ }^{l}$ Center for Research and Development for Public Health Effort, National Institute of Health Research and Development, Ministry of Health, Jakarta, Indonesia

*Corresponding author.E-mail: luxi@litbang.kemkes.go.id

\begin{abstract}
Housewives are the highest sufferers in 2013-2017 cumulative AIDS data in Indonesia. Prevention and Antiretroviral Treatment (ART) of HIV need to be completed proximately, especially on pregnant women. We conducted qualitative research about HIV test, ART and health services for pregnant women in Kota Kupang and Yayasan Bumi Sehat, Ubud. The research objective is to identify obstacles to HIV test and ART for pregnant women and to identify improvement model. Method: Research was accomplished through indepth interview and Focus Group Discussion. Topic of HIV test and ART in Kupang were asked to 55 respondents. HIV test and health service in Bumi Sehat were asked to 9 persons. Discussions were about the importance of HIV programs on pregnant women (PMTCT) and expectations/proposed models. Themes that come up then combined to be concluded and to make recommendation. Results: Pregnant women and their husband did not have complete knowledge of HIV and ART, while health officers doubted to give HIV test because of unprepared local policies and incomplete facilities. After given explanation, the husbands willing to support and suggest mobile clinic on weekend beside involvements of private clinics. However, pregnant women who were not officially married have difficulty getting support from their husbands. According to ART, stigma on HIV pregnant and postpartum women made them needs to move. Economy difficulty also hinders them. Bumi Sehat builds trust and loving relationship within staffs and with patients and family that their health services respected. After increasing community awareness, HIV test accepted by all for years. It is also integrated with health services. Committed HIV counselor that works also in hospital alleviates the referral of HIV cases. Conclusion: Obstacles to HIV test and ART for pregnant and postpartum women were incomplete knowledge of HIV and ART on community and lack of policy and facilities. To improve, it needs support from leaders, integrated health services, and a loving and trusted relationship within health workers and with their patients and family. The recommendation is good model of integrated health service for HIV test and ART on pregnant and postpartum women need to be established and supported by all.
\end{abstract}

Keywords: Antiretroviral Treatment, HIV test, pregnant women, prevention of mother-to-child transmission

\section{INTRODUCTION}

Sustainable Development Goals (SDGs) in the third goal of good health with several targets including improving maternal health and combating HIV and AIDS are the foundation of the importance of this research. The related targets in 2030 are reducing maternal mortality, reducing neonatal and under-five mortality rates, and ending the AIDS epidemic [1]. Likewise, the Ministry of Health's Strategic Plan for 2015-2019 still prioritizes HIV/AIDS in the case of infectious diseases [2]. The importance of preventing HIV transmission to children is getting stronger because without proper and early treatment, $50 \%$ of children infected with HIV will die before their 2nd birthday. Meanwhile, according to the report the fastest transmission of HIV and AIDS in Asia is now in Indonesia [3].

The importance of Sexual Transmitted Infections (STIs) increases as the epidemic of HIV-AIDS happening, which is actually also STIs and which is often fatal because it has been proven that the presence of other STI infections facilitates HIV transmission [4]. In Indonesia, there is an increasing trend of Housewives who suffer from AIDS. As 
of September 2013 there were 5353 housewives with AIDS cases out of 45,650 total cumulative cases in Indonesia and from July-September 2013, the highest AIDS cases occurred in housewives with 347 cases [5]. The AIDS cases reflect conditions that need more treatment because they increase risk to Opportunistic Infections and may have been delayed in the initiation of HIV testing and ART. Therefore, it is important to conduct an HIV test immediately for housewives located in areas with a high prevalence of STIs and HIV, because STIs increase the risk of HIV three to four times [4].

This paper is taken from research data on prevalence of Reproductive Tract Infections (RTI) and HIV in several cities. In the city of Kupang, qualitative research was conducted to explore matters related to pregnant women for HIV testing and for pregnant women PLWHA (People Living with HIV/AIDS) to start ART. RTI-STI-HIV data for pregnant women in the general population is needed to advocate for resources and interventions for reproductive health and HIV programs, to design appropriate interventions, and to monitor and measure program effectiveness. Furthermore, it is estimated that there is a need for a model of health care for pregnant women that has succeeded in helping to reduce death and illness. Bumi Sehat Clinic in Ubud, Bali has providing excellent service so that its founders won the CNN Hero of the Year Award. Qualitative research was conducted on the excellent service provided by officers at Bumi Sehat Clinic and how the founder of this clinic can motivate staffs who serve to innovate the best and create a pleasant environment for pregnant women and their families. The aim of this paper is to identify obstacles to HIV test and ART for pregnant women and to identify improvement model.

\section{METHOD}

This study used qualitative descriptive design in order to obtain in-depth information on the causes of the low participation of pregnant women to be tested for HIV and STI and to start ART, and model of good health service for it. The sites were City of Kupang, NTT (Nusa Tenggara Timur) and Ubud, Bali while accomplishment was in 2017. The informants for in-depth interviews or with FGD or round table discussions are:

Informants in Kupang: pregnant women (who are willing to test and who refused), 4 people; pregnant PLWHA who are willing to take ART, 2 people; pregnant women's husband, 2 people; midwives in the study area of PKM/Puskesmas (Public Health Centre) (PKM Bakunase, Sikumana, Oesapa, Oepoi, Alak, and Penfui) who have private practices, 4 people; the head of the PKM, Poned (with Basic Emergency Neonatal Obstetric Services) and non-Poned mentioned above, the Coordinating Midwives, and laboratory analysts, 18 people; the PMTCT/VCT team in Yohanes Hospital and TNI Wira Sakti Hospital and NTT Provincial Health Office, 14 people; the PMTCT program team in the Kupang Regional Health Office, 4 people;
Round Table Discussion of community leaders: representatives of traditional leaders, representatives of religious leaders, representatives of youth leaders, and NTT Provincial AIDS Commission, Kupang City AIDS Commission, Sikka District AIDS Commission, 7 people. Informants in Bumi Sehat clinic: leader, staffs, counselor, two pairs of pregnant women/postpartum with her husband, midwifes, 9 people.

The inclusion criteria were:

a. Pregnant women who receive tests: have done HIV rapid tests twice; pregnant women who refuse testing: have been offered HIV tests by health workers in the MCH/FP clinic and refused; Pregnant PLWHA: Pregnant women who have HIV positive.

b. Pregnant women's husband: husband of pregnant woman respondents in qualitative research

c. PMTCT program team: people involved with the Prevention of HIV-AIDS transmission from Mother to Child program

d. Willing to participate by signing the consent form (after reading or reading the informed consent)

The interview guide contains a list of main questions about the question variables. Data obtained in the field are made into transcript. Then, research team discusses the themes obtained and assembles the continuity of the themes in each group of respondents, then between groups of respondents. After that a detailed analysis of the themes and their continuity is carried out to obtain an overall picture of the data. Finally, to make a model to provide input for increasing the participation of pregnant women with HIV and STI testing at the MCH/FP-STI clinic, and to start/continue the ART program for pregnant women living with HIV.

\section{RESULTS AND DISCUSSION}

The qualitative data result of this research was written in two big parts, one is of the Kupang and another is of Bumi Sehat. In Kupang, the study was conducted to determine the needs and expectations of HIV test and ART services and in Bumi Sehat clinic as a model of health services for pregnant women that already has successful on HIV and Syphilis test.

A. Qualitative Data Needs and Expectation for HIV Tests and Services in Kupang City

The data that has been collected is described as follows in accordance with the topic / theme.

a. Knowledge of MCH services and HIV testing on pregnant women and related matters

Knowledge about maternal and child health services and HIV testing varies greatly between the general population represented by pregnant women and their husbands, PLWHA and their husbands, health workers, and community leaders in Kupang City. Pregnant informants who have taken an HIV test and received an explanation before the test have sufficient knowledge even though it is incomplete and there is still wrong information. They know that HIV can be contagious and is caused by sexual intercourse with multiple partners. The informant said if the 
symptoms of HIV were weight loss, so that was the way to identify HIV. The informant stated that HIV could be treated and could cause death, but had never heard and knew about government HIV program. They also said to avoid getting HIV by taking drugs and the way to avoid HIV transmission is by not changing partners. They gained knowledge about HIV from the 2015 socialization program at the church and the official who provided the explanation came from the HIV office (Regional AIDS Commission). The City Health Office has not yet provided information related to HIV. Information on how to prevent HIV is obtained from the health center. Other pregnant women who have tested for HIV know that condoms are used to prevent transmission of STDs, but have never seen a condom and do not know what it looks like. The informant stated that he had received counseling a month before the interview about HIV at the Nurwan Sabu Puskesmas in Marbaroyan (not the PKM where this study was conducted) and if the husband was infected with HIV he had to be taken to the hospital to be treated so he would not transmit it to his wife.

One informant who has never tested for HIV has less knowledge of HIV and there is still wrong information. According to informant, HIV/AIDS transmitted through free sex and not hereditary disease, but can also be transmitted through skin contact. The informant said that to avoid transmission is by maintaining cleanliness and not having free sex. Regarding the transmission of HIV/AIDS from mother to child, the informant claimed she did not know and had not received sufficient information. Informants also have not received information that HIV testing and treatment is free. From information on television informant know that people must take HIV test if they carry out risky behaviors. Other informant who has not been tested apparently already has sufficient knowledge about HIV from counseling by health workers, but knowledge about the presence of antiretroviral as treatment for HIV is unknown. Respondents that had never been tested for HIV because of fear of being found out the test results positive was changed after a short discussion and were willing to test for HIV if the government had required and paid by the government.

Informants who refused the test turned out to have better knowledge than pregnant women who had and had not yet tested. They already know that HIV is a virus and will transmitted through sexual contact. They also know HIV prevention by not having sex with multiple partners and know the prevention of HIV transmission to pregnant women by using condoms during sexual intercourse. However, there are still shortcomings, they consider that $\mathrm{HIV}$ is not an infectious disease and do not know about the government program to prevent and treat HIV (ART). One of the informants ever had Health Promotion about HIV in school and church given in 2015 by doctors and was given a book containing HIV-related knowledge. The contents of counseling about HIV are venereal diseases related to blood. While, the husband of this informant worked in Puskesmas, but apparently he did not know that there was HIV test at Puskesmas and did not know about HIV prevention even though had little knowledge about HIV treatment.

Two mothers with HIV-AIDS or PLWHA who had just given birth a few months ago when interviewed had very good knowledge about HIV/AIDS. They know the source of transmission, methods of transmission, prevention and treatment from various training and seminars for peer groups managed by Local AIDS Commission and NGOs. The husband of one of the mothers was also well informed because he also received counseling to support his wife. Other PLWHA do not have a husband because he has died of AIDS.

The village midwife in a village with 2 HIV positive pregnant women, have low understanding of PMTCT because they were not aware of the existence of the Program. As part of program services officer, they still do not know and understand the technical of HIV services that are part of the PMTCT Program/Activities. Training and outreach is needed to cover all stakeholders involved in the program/activities because the village was located close to the border of the city, there was a brothel, and is close to the seaport. Unfortunately, a private practice midwife in one of the Puskesmas in the middle of the city also stated that they did not know about HIV and were afraid to carry out examinations of patients with HIV. Even though the midwife serves patients at least 5-6 people per day at her home and there were often patients with complaints of vaginal discharge and itching, which is an indication for STI examination. The midwife considers normal cases of pregnant women with vaginal discharge and itching.

"Because the one who came here, check, there is only vaginal discharge; For pregnant women, vaginal discharge is at least normal ... with itching (midwife I)"

"Karena yang dong datang periksa disini keluhannya cuman ada keputihan; Untuk ibu hamil kan keputihan setidaknya normal ... dengan gatal-gatal (bidan I)"

b. Culture and attitudes about MCH, HIV testing and treatment

From two pregnant women informants who refused HIV testing, the initial reason was that health workers did not ask pregnant women for HIV testing. But when it was continued or further explored, the informant expressed fear to carry out the test. This is what he stated:

"Sonde (meaning: no) ... takut saja begitu (just be afraid)" (vr)

In an area where 2 HIV positive pregnant women were found in this study, some unhealthy sexual behaviors were found, such as not having sexual relations with a partner, not using contraception, relationships without official marital status because they had not yet completed the customary marriage requirements, and there is a men's gathering to finance sexual relations in the brothel in the area. It was also stated that there was a lack of awareness for people with HIV or STIs to seek treatment at the Puskesmas/Hospital. Some even dropped out of ART 
because the family considered the patients is not medically sick, so that they trusted the shaman for treatment, which eventually resulted in death for the HIV patient. Pregnant women in this area who want to do an HIV test say they want a test because they feel that their husband's work is risky and after getting an explanation, they will encourage other pregnant mothers to take an HIV test.

"So we have to test, we don't know that the husband outside is related to other women carrying the disease, we don't know (nk)"

"Jadi kita harus tes, kita tidak tau suami diluar berhubungan dengan perempuan lain membawa penyakit, kita tidak tau (nk)"

Related to culture, there is experience according to health workers: the pregnant woman's HIV status is closed to inlaws who also take care of the birth of her daughter-in-law and raises questions because the postpartum mother does not breastfeed her baby, while the mother-in-law prepares the ingredients so that breast milk is abundant and looks successful. A very patrilineal tribe such as the Timor which is recognized as the most tribal by pregnant women informants of this study, makes women fully regulated by their husband's family, especially if the finances of young families are still assisted by parents. But it is also recognized that with the changing times this can be changed, depending on women/pregnant women how to organize and communicate with their families.

c. Needs and expectations according to pregnant women and husbands, PLWHA pregnant women and husbands, and health workers

Some needs and expectations expressed are:

- Kupang Health Office did not have budget for HIV testing on pregnant women because the proposed budget has not been granted, so they have no courage to ask Puskesmas to implement the program. There are BOK/Bantuan Operasional Kesehatan (Health Operational Aid), the use of which is partly for the Maternal and Child Health program carried out by midwives such as affixing P4K (Program Perencanaan Persalinan dan Pencegahan Komplikasi/Delivery Planning and Complication Prevention Program) stickers; visits for pregnant women, at-risk neonates, high-risk pregnant women; for Mother's Classes; and to detect pregnant women and RTI. In addition there is assistance from formula milk companies in the form of financing midwives/doctors who provide counseling and gifts for pregnant women.

- Puskesmas that have provided HIV testing to key populations conduct free HIV examinations for patients with electronic ID, patients with National Health Insurance, and patients with temporary Kupang City ID. A general patient pays a ticket of Rp. 5,000, the same as other patients. There is no regulation related to funding/payment for HIV testing, so all are free according to the terms of the Kupang Health Office. Kupang City Regional Regulations are needed and clear financing from the budget set by the Kupang City Government. The Puskesmas makes a policy for pregnant women who do not have health insurance, so they are required to make it, and if the poor can ask for assistance from the Health Department by guaranteeing money for childbirth assistance. If not, then it is required to pay Rp. 650,000 for administrative order. If it needs to be referred, it will be referred. At the time of the interview, even PLWHA who were on treatment one of them did not has her own Health Insurance and the other PLWHA had Health Insurance but could not pay her contributions for the past year. They are made easy in obtaining ARVs by paying monthly medical registration fees because they do not yet have an electronic ID card, came from another area but live in the city of Kupang, and were poor. There needs to be a provision to alleviate the costs of pregnant women and PLWHA and their families who are poor and do not have Health Insurance so that they can be examined and treated. - HIV and Hepatitis tests were proposed to be carried out in private practice midwives also. This was stated by one of the pregnant women who had not tested and felt comfortable checking with private practice midwives and heard that midwife services at the Puskesmas were not friendly. Another private practice midwife who did not yet understand HIV also said that she needed training on HIV and STIs, and felt that she needed to be equipped for the services.

- It is necessary to promote HIV and AIDS programs and STIs in the younger generation as it is realized by lay informants that the most victims are young people. It is also needed the ease of information that is spread on cellular phones or social media with applications on cellular phones. There is also a need for more mobile clinics with prior notice and explanation, because for examinations like this people tend to be mentally 'lazy to go to the clinic' to check. - Health workers, especially those dealing directly with the community in the satellite Puskesmas, feel the need for additional salaries because of the risks faced and the existence of additional salaries can help them do more.

- One PLHIV who has given birth to an HIV positive child, but cannot care for her child, has tried to give ARV from the program to her child who is being cared by her husband's family but rejected. The informant's husband who transmitted HIV to her already died and her husband's family did not understand the HIV problems of their child, daughter-in-law, and grandchild. The HIV positive mothers found it very difficult and burdened with the condition of their children without ARV so it is recommended that other PLWHA plan carefully if they want to have children, and do not need to have children if they are unable to care for themselves properly. There is a Shelter Home for PLWHA who need a place to live because they have been ostracized by the community or PLWHA from other areas during treatment at the referral hospital.

d. Mother and Child Health Service Model in Kupang City

Existing service model in Kupang City is described as below:

- According to one pregnant woman who refused the test, health workers at Puskesmas did not recommend HIV testing on pregnant women because they knew that pregnant women were fine even though at the Puskesmas there was a public HIV testing facility. For the program, even though it 
already exists, it still felt fragmented as some of it is run by Local AIDS Commission, partly by NGOs, so there is confusion in the data sometimes. The Foundation 'Without Border' started to pay attention to HIV cases in women in the city of Kupang, then formed the Local AIDS Commission. Pregnant PLWHA recorded in the register for special treatment and in collaboration with relevant institutions or agencies to give special notes to pregnant PLWHA so that health workers, especially midwives can prepare themselves better with PPE (Personal Protective Equipment). Health Office and cross-program collaboration has been required stakeholders, community leaders, religious leaders, and youth leaders to educate the community/congregation to behave in a healthy manner.

- Kupang City Local AIDS Commission has also begun to be active by forming WPA (Warga Peduli AIDS) or AIDS Concerned Residents who invite people to test for HIV starting from 2016 in the Oesapa area at its vulnerable points. It is estimated there are a thousand more residents with mobile VCT. For technical readiness and procurement, VCT is prepared in the first Puskesmas and SK Lerik Hospital located in Kupang City. A PLWHA that found will be referred for ARV to Yohanes General Hospital through Sobat VCT Clinic. For ART, the provision is still considering several things and was on preparation. Like the SIHA reporting system, assistance in the new SK Lerik City Hospital would be managed, after all this time had received training but had not yet started the service because it was not under the coordination of the Kupang City Health Office previously. It is also planned that the possibility of preparing a Satellite Health Center for ART services, especially for PLWHA, who is categorized as capable and can be served at the Puskesmas while still being accompanied by a specialist doctor from the Kupang City Hospital SK Lerik. The VCT Hospital service is planned to start moving at the end of 2017.

B. The Bumi Sehat Clinic health service model The Bumi Sehat Foundation located in Nyuh Kuning, Ubud, Bali is a non-profit organization and initially provided free health services to pregnant women since 1995 . The founder is Mrs. Robin Lim, a registered midwife in the United States and in Indonesia. Recently, Bumi Sehat health services are also available in Aceh and in Philippine that are also provided with educational services, disaster recovery, humanitarian services, in addition to quality health services. In health services, this clinic provides allopathic and holistic services (conventional and comprehensive) in pre and postnatal care, support for nursing mothers, infant, toddler and family health services, as well as nutrition education, yoga for pregnant women, and gentle and relaxing normal birth methods. Although the method of birth is as natural as possible, the equipment available is very good and up to date, thus speeding up the service and accuracy of the examinations. All pregnant women that come are willing to be tested for HIV, syphilis, and all other as the program for pregnant women since 2013, succeeding the education and test on all midwives. The following are some of the main things that make Bumi Sehat clinic services good and can be a role model for public health centers, especially for maternal and children health services that provide successful HIV and STI tests.

1. Have the philosophy adopted by Mrs. Robin Lim and taught to midwives, nurses and clinic staffs: love the midwife profession and feel the most noble with the nurse profession because they helps humans come to earth and needs to welcome babies as best they can in hope of getting good children of future generation who love peace. Mrs. Robin Lim does not induce anything to the midwives; whatever they want to do that important for the patient to be comfortable, relaxed, and safe.

2. Gentle birth method prioritizes patients, not only during labor but also from the first pregnant woman comes to the clinic to have regular antenatal care so that pregnant women feel comfortable and confident to be able to give birth normally. It all starts with a general practitioner consultation to find out if there are special needs.

3. Some principles of pregnant women health services:

a. It is not a problem if patients are poor because they will get full and loving services. All patients were welcomed and greeted with the words "I love you" while being embraced; also on a daily basis among leaders and staffs.

b. Confidentiality is important so that it is taken care of.

c. Patients trust the midwife so that there is no difficulty in testing for HIV.

d. There is a particular HIV counselor.

4. How to build a "Trust" between midwives and patients:

a. Trust is built by being friendly, smiling sincerely.

b. Senior midwives taught young midwives how to behave towards patients as patients cannot choose which to serve, thus all midwives can serve all.

c. In the past, although it was difficult, midwives persuasively explained to pregnant women the importance of HIV testing because there is Antiretroviral Treatment if they were positive and so they would not transmitted to their infants.

5. In obstetric and gynecologic services, several things are done by Bumi Sehat clinic:

a. Pay close attention to the implementation of Medical Science in full. All staffs receive training both in the clinic and given the opportunity for higher levels in universities and courses outside.

b. Respect the natural way of labor by preparing well. If there are conditions that are known to be impossible, the patient is referred to hospital. They are aware the risks and losses of babies born by cesarean, both to the baby and the country due to subsequent health conditions.

c. Respect the culture and religion adopted by each patient and collaborates with clergy of various religions. Related facilities are provided.

d. Support for postpartum women after giving birth is a home visit if the mother has difficulty in breastfeeding and contacting the clinic. If possible, they will be referred to the nearest village midwife initially.

e. The clinic has applied a one-door system through registration for all polyclinics since October 2016. In general polyclinic there are 4 general practitioners and 4 nurses who work by shift every day but not 24 hours, i.e. from 8 am to $8 \mathrm{pm}$. In the lab, the clinic has two analysts 
and one HIV/AIDS counselor. The HIV and Syphilis test are free, funded by donations.

f. Examination of laboratories in the clinic: HDL, routine hematology; and hepatitis B, syphilis, HIV with rapid tests. For the rapid test they purchase the equipment/reagents, and those used are the same as those used by the program. HIV and syphilis testing are given in the first quarter of pregnancy, but if a pregnant woman comes in old age of her pregnancy she will be tested immediately. The test is required at least once during pregnancy. There is a bacterial examination with a vaginal swab and a microscope too. Blood tests are done using a Hemolizer machine 3.

g. Midwives also recommend pregnant women to double check up to a more complete Obstetric and Gynecologist Specialist or hospital.

h. This clinic serves as a complementary clinic. For labor, there are no induction services, excitatory injections, infusions, Pap smear, epidural administration, and painkillers. If necessary, induction is given with acupuncture.

i. There is a labor preparation class in order to make them ready to face the pain. Preparation classes aimed at first pregnancies and pregnancy yoga 2 times a week for mothers of gestational age after 6 months until before give birth. They are taught how to manage breathing, stretching, and managing pain. On Saturday, childbirth preparation classes and babywearing classes are held in collaboration with the babywearing community. The clinic prepares the patient's mentality and knowledge with education, such as about nutrition and a healthy lifestyle. If the patient requests to be provided services that are not provided by the clinic, the patient will be referred. Antenatal care is carried out 3 times a week on Tuesday, Thursday, and Saturday at $5 \mathrm{pm}$ until completion because is held at the same time as pregnancy yoga. Performed in the afternoon because pregnant women prefer in the afternoon. If there are pregnant women who cannot come as scheduled, they can immediately come another day because midwives stand by for 24 hours. There are 12 midwives and a 12-hours shift work schedule. Three delivery rooms available and one special room for antenatal care are in very good, clean and comfortable conditions. There is an ultrasound machine, used when reckoned necessary or there is something important and needs to be checked. From 30-50 services per month there are only about 3 patients referred.

j. Antenatal care given to pregnant women more often than government programs. The first trimester is not once but every month, the second trimester is not once but every two weeks, and the third trimester is not twice but every week. Pregnant husbands are asked to actively participate in pregnancy check-ups and yoga, so that husbands are also educated. Some were asked to stop smoking persuasively and successfully quit.

k. Pregnant women are free to give birth with any position, not necessarily lying in Obgyn-bed. There are also birthing balls that can be occupied to help, especially for those whose water birth has not broken. The delivery method was adjusted to the Indonesian Midwives Association program (Ikatan Bidan Indonesia).
1. Gerakan Sayang Ibu (GSI) or the Love Mother Movement that approached from Indonesia $\mathrm{MoH}$ is similar to the gentle birth but has not been implemented properly. It is still only theories; implementation techniques have not yet been developed and applied. Gentle birth is more interpreted to the treatment of patients, such as the tone of her voice, and also does not force to be fast (in the process of giving birth) so that there are maternal figures who help and accompany childbirth. It is important patients feel comfortable, safe and relaxed as midwives treat them like relatives. Midwives prioritize communication to patients so that patients can easily receive education.

$\mathrm{m}$. Postpartum rooms in the clinic are used for mothers and babies after delivery. They are put in the same bed and baby is immediately put into the mother's breast for Early Breastfeeding Initiation (Inisiasi Menyusui Dini). A postpartum mother whose milk is not yet smooth is assisted with chlorophyll and spirulina, which given freely. If a child is born with problems, he will be consulted to a pediatrician and then referred to other health facilities. There is an obstetrics and gynecologist specialist as a consultant for this clinic. Every month the clinic submits a report to Puskesmas.

n. For pregnant women infected with HIV or STIs, even though they cannot give birth at the clinic, the HIV counselor accompanies them to deliver in the hospital. The clinic's HIV counselor works also as a counselor in a referral hospital and builds networks with doctors in Ubud area.

o. Pregnant women have KIA (Mother and Child Health) pink book similar to $\mathrm{MoH}$ program book.

6. Every family is given some books about exclusive breastfeeding and is taught how to do it, including the husband to help. All is available online through website.

7. For HIV testing on pregnant women, Bumi Sehat Clinic has been doing it since 2013 because of seeing its needs. Stigma and discrimination are still high against PLWHA in Bali. Health promotion about HIV-AIDS is carried out continuously with relevant NGOs and since there is ART the situation is improving. The PITC program for pregnant women has begun in Denpasar before there is a Ministerial Regulation. The HIV testing at the Bumi Sehat clinic began due to the fear of midwives helping PLWHA give birth normally without knowing their status. With the explanation and tests of all midwives, the PMTCT program began. All pregnant women are tested; positive and negative checkpoints are the same to protect confidentiality. Explanation is given until the pregnant woman understands enough and the counselor can help according to the agreement through the easiest communication. For HIV positive pregnant women, ART and childbirth performed at Sanjiwani Hospital and STIs treatment at Puskesmas Ubud II. Husband of a HIV positive pregnant woman is examined too, and if negative at early will continue to be monitored by retest until after delivery. In Bali, there is a Regional Regulation, namely sanctions/fines if a partner from a PLWHA turns positive. 
Results of health service efforts provided:

1. Most husbands want to support correctly after being explained.

2. There is satisfaction from all staffs because the clinic facilities are adequately complete and leaders who always provide inspiration and role models about serving with love. The cleanliness of the clinic is also very much taken care of so that all are very comfortable.

3. All pregnant women willing to be tested for HIV, Syphilis, and Hepatitis in addition to antenatal care according to pregnant women's health programs. Likewise, the husband of an infected pregnant mother is willing to be tested. Furthermore, all infected ones are willing to be treated.

To improve the services of pregnant women in Indonesia, Ibu Robin Lim, midwife and couples suggested:

1. In addition to direct education to the community about HIV, it is also important to reinvest the role of midwives so that pregnant women are prepared for normal childbirth.

2. Pregnant couples expect Puskesmas officers to provide Health Promotion more frequently to Balai Banjar in villages. A postpartum mothers say accordingly:

"For health promotion in the community in banjar, the officer who gives it is accompanied by Klian or the Banjar administrator. In addition, we want to get free medical treatment without paying even more (already member of BPJS/national health insurance), because I already pay it every month "(postpartum mother)

"Untuk promkes di masyarakat di banjar, petugas yang memberi didampingi Klian atau pengurus banjar. Selain itu, kami maunya jika berobat gratis tanpa bayar walaupun sudah BPJS, karena saya bayar tiap bulan" (ibu nifas)

3. There is a good principle in Bumi Sehat: everyone is a VIP (Very Important Person) because in the eyes of God who created humans we are all VIPs. This is a principle or philosophy that is very good if practiced throughout Indonesia. According to respondents who gave birth in public hospitals:

"Service in public hospitals is not good because the officers are not friendly by shouting and when the patient is in pain does not sympathize and even says offensive things such as: how you make the baby, is it hurts too!" (Postpartum mother)

"Pelayanan di rs umum kurang baik karena petugas tidak ramah dengan membentak-bentak dan bila pasien kesakitan tidak bersimpati bahkan mengatakan hal yang menyinggung seperti: bagaimana bikinnya dulu apa sakit juga!" (ibu nifas)

4. To involve the husband, the midwife provides an appropriate explanation of the various risks that her husband and baby will face whether in near or in the future. 5. Ms. Robin Lim's hopes for improving maternal health services: support to midwives and nurses who are grassroots services, who are in-touch with patients throughout the day and close to the community. In this clinic, all midwives who give birth get maternity leave for 6 months in order to be able to give exclusive breastfeeding and take care of the baby while still being given full salary.

6. The Bumi Sehat clinic service model is duplicated as widely as possible, with a vision and mission as the clinic does and continues to improve.

7. A $100 \%$ breastfeeding must be sought and there is no binding cooperation with milk formula companies such as baby rooms funded by dairy companies.

8. Obstetrics and gynecology specialists do not scare patients into performing cesarean operation. Even it has to be cesarean because of certain conditions, it needs to be helped so that the Early Breastfeeding Initiation is carried out.

9. Simple and loving management really helps all.

10. Midwives claim that pregnant mother's husband also need to be examined for STIs and HIV, because midwives recommend patients to have sex with their husbands as it is known that sperm can help in straining the cervix when the patient is already in third trimester pregnancy. Midwives suggest condom use if couples want to have sex while pregnant during an infection, but if use a condom sperm certainly cannot help. Therefore, it is important to check infection with the pregnant mother from the start. Just before delivery, if there are no contractions, pregnant women are advised to have sex with her husband.

11. According to the HIV-AIDS counselor, HIV testing procedures should: easy access; effective discussion, that HIV is not a scary disease; the counselor's appearance is more populist, and family atmosphere created; both positive and negative go through the same path, so it is not differentiated; effective time or not queued for too long and made flexible so can be done in the morning or afternoon or at night.

12. Input for PMTCT counselor training: prospective counselors are tested before being trained to be selected who truly intend and are willing to give time to counsel the patient. Should not be a double-job health worker; it is necessary to practice while training so that it is not just the provision of information or knowledge; able to explain in language that is easily understood by patient/community; and activate those who have been trained because there are enough trained counselors.

Pregnant women can get the same STIs as women who are not pregnant because pregnancy does not provide additional protection for both the mother and the infant. Some of these diseases cause no symptoms, consequently many women do not know if they have been infected. Pregnant women need to get an STI examination, including HIV, as part of their antenatal care and examination. The existence of STIs during pregnancy can have serious and even dangerous consequences for the lives of mothers and children. Therefore, it is important for women to know the risks of STIs and how to protect themselves and their infants against infections. Spouses of infected mothers should also be examined and treated. Adverse effects of STIs can add to complications in pregnancy and harm the growing baby. The effect can be seen immediately when the baby is born, but it can also be several months or years later. These 
problems can be avoided if pregnant women receive routine pregnancy care and examination, including STI tests as early as possible in pregnancy and are repeated before delivery if needed [6].

Human Immunodeficiency Virus is a virus that causes AIDS or a collection of symptoms of disease due to decreased immunity. This virus attacks certain blood cells that are important for the body to fight disease. This virus is found in the bodily fluids of people who have been infected, namely in blood, semen, vaginal fluid, and breast milk. People Living with HIV cannot be recognized by seeing directly because it is without symptoms. Thus, it is necessary to do a blood test to prove it. If the HIV status of a pregnant woman is known before or during pregnancy and the best efforts are made immediately, then the risk of HIV transmission from mother to child can be reduced to only $2 \%$. Therefore, it is highly recommended that all pregnant women get an HIV test. Pregnant women who know their HIV positive status earlier have more time to consult with health professionals and decide what is best to protect themselves and their babies [7], [8].

Equally, couples of pregnant women should do the test. In most cases, HIV is not transmitted from the mother to her fetus through the placenta. If the mother is healthy in other aspects, the placenta will protect the growing fetus. Some factors that can reduce the protection of the placenta in fetus in HIV-positive mothers are: infection in the uterus, new HIV, HIV in advanced stages, or malnutrition. Other factors mentioned also increase the risk of infants getting HIV from their mothers: smoking, drug use, Vitamin A deficiency, STDs, viral load, factors related to the process before delivery and during labor. Nutrition counseling for pregnant women with HIV is emphasized to avoid iron and Vitamin A deficiency, as well as to avoid underweight and to avoid new infections such as RTI, Tuberculosis or other respiratory infections, and malaria. Health workers also need to avoid invasive treatment to pregnant women to avoid transmission to their children. The attention that is needed during labor is not only medical that is handled by specialists, it also requires assistance from social services such as food handling, housing, child care, and how to be a good parent [9].

According to the report of this whole research, it can be said that all pregnant women in this research are pregnant women who access MCH services. However, in the last 3 months the majority have never been referred to discuss pregnancy and have never visited the $\mathrm{MCH} /$ Family Planning (FP)/STI clinic for internal and STI examinations in all 4 sites. Of the few interviewed in Kupang, the researcher remembered that there was a recognition that pregnant women preferred to go to the midwife or the nearest private practice doctor because they did not need to wait in line at the Puskesmas for too long. However, those who were examined without complaint and found that the laboratory results were declared to be infected said that they had reported to the midwife or private practice doctor and were considered normal without being referred for laboratory examination [10]. This is also admitted by private practice midwife that become an informant of the qualitative research. Midwife I, a private practice midwife in one of the Puskesmas in the middle of the city stated that they did not know about HIV and were afraid to carry out examinations of patients with HIV. The midwife serves at least 5-6 patients per day at her home and there are often patients with complaints of vaginal discharge and itching, which is an indication for STI examination. The midwife considers normal cases of pregnant women with vaginal discharge and itching.

From the results of the Ministry of Health's research in several provinces, the average median quality of antenatal services in health facilities which is based on an assessment of health workers, in hospitals by $51 \%$, and in health centers by $58 \%$. While the average median quality of delivery services at both hospitals and health centers is the same, at $74 \%$ [11]. Whereas the incidence of maternal death is largely determined by the quality of services provided by health workers. Therefore, the quality of delivery and antenatal care services at Puskesmas and hospitals needs to be invigorated.

Furthermore need to be promoted is the awareness of community of what is the risks of STIs and HIV on pregnant women and the importance for tests and prevention, including the availability of ART. As the risk behavior still practiced by husbands of pregnant women, prevention by using condom when having sex intercourse also need to be accomplished, along with the willingness of husbands to be tested and treated also. Ibu Robin admitted, since the knowledge of free ART that available for PLWHA given, it is easier to persuade pregnant women to be tested. Health promotion of HIV have been done sporadically to communities in Kupang, it seems the knowledge not comprehensively understood and mostly now aware the availability of free ART for any PLWHA. Collaboration with relevant NGOs needs to be increased not only to give health promotion, but also to successful implementation of PMTCT. Having health promotion been risen in communities, it can be expected that stigma and seclusion of PLWHA, especially for pregnant women and their children will be reduced. This has been stated as important by two PLWHA mothers who have cruel experience because of the stigma and dominancy of husband family according to their culture. They stay in shelter house because the need to keep on ART. Usually, community did not accept PLWHA and the economic difficulties sometimes make them stop to go to health centre/hospital and need help from NGOs and Local AIDS Commission.

Moreover, policy makers have to provide support through legitimacy and budget for PMTCT program. Delay on having both has halted the accomplishment of it. This has lead to doubtful health officers on PITC and lack of coordination among some institutions on doing health promotion and HIV test. In term of the role of health services in the city related with HIV, facilitating factors included valuing pregnant women lived experience; trust building and accommodating PLWHA's needs are really 
important [12]. Likewise in Kupang, a trained health service workforce is critical to ensuring good quality service delivery to people with HIV. There is need for comprehensive and appropriate training for health care providers to build their capacity to meet the requirements and expectations of different sub-populations of HIV positive people. Finally, counseling skills are critical for those serving people with HIV, but skills vary widely in depth and quality across settings. As regards the way in which HIV testing should be offered, the proposed policy that pregnant women must routinely be offered an HIV test through either an "opt-in" or "opt-out" model is in fact still contested [13].

Bumi Sehat has gone through the uneasy initial HIV and Syphilis test program integrated with antenatal care. They have started to do the test to all pregnant women along with Bali policy and prior to Indonesia program, [14], [15], because not only understand the importance to the community, but also to the health workers who need to be protected also. Initially, Bumi Sehat worked together with NGO that work on HIV things to give education to the community through many activities. Some research found that pregnant women who are having more knowledge about PMTCT and know the importance to take the tests are more willing to take the test than pregnant women who has less knowledge about HIV and the importance of the test [16], [17], [18], [19]. Yuriati [16], in a research in Tanjung Pinang mentions that the education need to be in creative way and explain the whole things that needed to be understand by pregnant women and family such as Hemoglobin test, blood type, hepatitis test, and HIV test, and explain the intent and purpose. Furthermore, if the results of the HIV test is negative, counselor or midwife still need to gives counseling to keep negative during pregnancy, breastfeeding and so on. If on the contrary, the counselor or midwife's give advice for the positive test results to continuing counseling, Antiretroviral treatment, and preparation for labor. This is in accordance with the implementation guidelines of HIV testing and counseling. These also found to be practiced by Bumi Sehat. Meanwhile, Legiati [17] reported that in Kota Semarang the education of PMTCT has been given to midwives and doctors in Puskesmas and Hospitals since 2007. Along with that, leaflets about VCT and PMTCT also given to community including to reproductive age woman and housewives.

In Denpasar city, Arniti [19] found that $65.8 \%$ of respondents revealed that they did an HIV test because of following the advice of health workers, $61.7 \%$ said because they wanted to know the status of HIV, $19.2 \%$ were due to protect children, $2.5 \%$ to protect partners and $1,7 \%$ because they feel they have a risk of contracting HIV. The reason for not receiving the test was $23.3 \%$ because they were afraid of blood taken, $18.3 \%$ were afraid of knowing the results of the test, $16.7 \%$ did not get a husband's permission. In bivariate analysis, variables significantly related to the acceptance of HIV testing by pregnant women, namely the status of pregnant women who are not working, knowledge about HIV and its transmission, perceptions of vulnerability to HIV/AIDS, perceptions of HIV/AIDS disease severity, the benefits of HIV testing, perceptions of HIV testing barriers and support husband or family. The results of multivariate analysis showed that the variables that increased acceptance of HIV testing in pregnant women were work status, perceptions of severity of HIV/AIDS and husband or family support. Mothers who did not work were 2.82 times more likely to receive an HIV test compared to women who worked (95\% CI: 1.07-7.42). Mothers who had high severity perceptions were 3.39 times more likely to receive an HIV test than mothers who had low severity perceptions about HIV/AIDS (95\% CI: 1.08-10.69). Mothers who had good support from their husband or family were 8.71 times more likely to receive an HIV test compared to mothers who had less support from their husband or family (95\% CI $=2.89-26.28)$. Similar pattern found in other research in Tanjung Pinang, Gresik, and Semarang [16], [17], [18].

However, there are some research that found there is no relationship between HIV knowledge and HIV test among pregnant women such as the research in Puskesmas Bergas, Kabupaten Semarang by Fitriani et al [20]. They found that there is relationship between works with HIV testing, in which case respondents who did not work $(75.0 \%)$ do tested for HIV compared to those who worked $(17.0 \%)$ because mothers who did not work have more plenty of time to visit the Puskesmas and carry out HIV testing while working mothers cannot take the time to do the tests. Mulyanti [21] in her study of pregnant women in Pontianak found several factors inhibiting pregnant women from taking an HIV test, namely distance and cost, and lacked information about HIV testing from health workers at the time of antenatal care. The last factor is can be caused by officers who are unable to carry out effective risk communication so that they are unable to provide health promotion and counseling. It was also mentioned that the double burden of health workers in Puskesmas might be the cause of lack communicative health workers. It was further revealed that pregnant women who had more information sources were more likely to take the test. Sources of information can be obtained from health workers, from electronic and print media, from friends or family, from health promotion in the community, and even from People Living with HIV-AIDS (PLWHA) in their neighborhoods. The urge to do the test is even stronger when pregnant women are aware of the vulnerability that they may experience to HIV transmission, especially if the pregnant woman or her partner travels far more than 1-3 days because it becomes a threat to have sexual intercourse with other people. Encouragement is also stronger when a neighbor is infected with HIV. But there are also vulnerabilities because women are less empowered so they do not have courage to take the decision to do the test. According to these findings, the health workers in Puskesmas has important roles in supporting more pregnant women to do HIV and Syphilis test when doing the antenatal care. 
Actually, since 2008 Ministry of Health already made statement that Puskesmas is the primary health service in the community, so it must lead the PMTCT effort. Integrated $\mathrm{MCH}$ services at Puskesmas can be a comprehensive screening for early detection, especially in prong 3 which is to prevent HIV transmission from HIV positive pregnant women to their infants. Subsequently, the risk of HIV transmission to infants conceived from HIV positive mothers can be reduced. Therefore, the role of MCH services in the Puskesmas is very important [22]. What made Bumi Sehat can have 100\% pregnant women tested for HIV and syphilis are because they serve in different way or serve pregnant women in the most suitable and comfortable to the needs of them. This clinic open until $8 \mathrm{pm}$ while there are midwives stand by for 24 hours. Pregnant women and husband or family can come after work in afternoon or nighttime to have an antenatal care including laboratory test. Thus, this answer variable mentioned in some research why it is more unemployed pregnant mother that is willing to be tested in Puskesmas as Puskesmas working hour limited to usual business hour. Primarily, a longer working hour through nice shift should be suggested to $\mathrm{MoH}$ and regional Health Office. This could arise the challenges on how to manage nice shift and whether health workers ask more salary. This has been managed by Bumi Sehat since beginning and Ibu Robin Lim made fair regulation to all midwives and other staffs so that no one reluctant to work on scheduled shift. Beside that, the prosperity and the support for staffs are very good that all staffs feel like working as precious serving to community in a lived-in environment. Full salary on 6 months maternity leave and chances to study more in Indonesia and abroad is also beneficial to increase staff's motivation.

Other factor that mentioned as supportive for HIV and syphilis test on pregnant women are supportive midwives or health workers and supportive husband and family of the pregnant women. Ernawati et al [18] in her research finding mentioned that pregnant women with good knowledge about HIV testing, perception of the severity of HIV disease are good and the role of midwives in providing counseling (PITC) is good, then it has a possibility of $83 \%$ to intend HIV testing. The role of midwives in providing health promotion is one of the reinforcing factors for HIV testing of pregnant women. This is because a person's actions are greatly influenced by the participation of health workers in motivating the community to take actions related to health. Efforts to provide continuous and integrated health promotion by midwives are supported by midwives' ability to manage health programs that can improve health behaviors for pregnant women. Support and encouragement from midwives could be taken as cues to action component according to Health Belief Model the researcher put in her paper. A good relationship between midviwes and clinic staffs has been developed in Bumi Sehat since the beginning pregnant women come to the clinic. Lived-in environment and warm welcome every time they visit the clinic support the trust of pregnant women and family to accept health promotion and health care given by all health workers in the clinic. The strategy to increase trust among pregnant women and midwives that practiced in Bumi Sehat should be introduced and developed in all Puskesmas in Indonesia. In addition to that is good relationship among staffs in a clinic. Nice work environment could lead to nice teamwork that is essential on serving pregnant women in their most important time of life.

Another suggestion from Bumi Sehat is the presence of particular HIV-AIDS counselor. Because the workload of midwives and staffs already occupied with health programs, it is better to employ dedicated counselor to give counseling to pregnant women and husband if needed. According to interview with counselor, the use of a particular skilled counselor could help a lot in managing infections problem that may asymptomatic but come up as risky behavior that was caught in enough counseling time provided. Midwives and other health staffs cannot give enough time to do that as they already have workload. Skilled counselor may help HIV positive pregnant women to be referred to hospital for more care and ART. This is very important to ensure that pregnant women with HIV can have ART immediately in the most convenience way and situations to hinder stigma and to provide best pregnancy and delivery care. It should be available through skilled assistance and management. Network of HIV counselor, doctors, clinics, and hospitals is essential for good PMTCT program. According to Minister of Health Decree in 2013 [23], the mechanism of relations between strata of services mainly takes the form of referrals that is a reciprocal reference between services. Referral includes referral patient, coaching and laboratory sample referral. In implementing reference, need to be considered in terms of distance, time, cost and efficiency. With thus, it is expected that the established cooperation network can provide better service to PLWHA pregnant women.

Treatment and prevention of HIV and STIs of Pregnant Women should be aware and provided by all health services, integrated to antennal care. Some infections such as Chlamydia, Gonorrhea, Syphilis, and Trichomoniasis can be cured with antibiotics that are safe for consumption during pregnancy. But STIs caused by viruses such as Herpes, Hepatitis B, and HIV cannot be cured. Antiviral treatment for infections caused by viruses is given to avoid transmission to the unborn baby. Furthermore, counseling about prevention of STIs during pregnancy needs to be provided. One of the best ways is to avoid having oral, anal or vaginal sex or to have only 1 partner (monogamy) known to be uninfected. For pregnant women who are on STI/s treatment other than HIV or their partners who are on treatment, it is very important to provide counseling so that pregnant woman and their partners do not have sex until treatment is considered to be completed properly. Male condoms used in an appropriate and consistent use can protect against infection and transmission of STIs and HIV [24].

\section{CONCLUSION}

Obstacles to HIV test and ART on pregnant women were incomplete knowledge of HIV and ART among pregnant 
[2] Kementerian Kesehatan RI. 2015. Rencana Strategis Kementerian Kesehatan RI 2015-2019 (Strategic Plan MoH RI). Kementerian Kesehatan RI. Jakarta

[3] Kementerian Kesehatan RI. 2014. Pedoman Pelaksanaan Pencegahan Penularan HIV dan Sifilis dari Ibu ke Anak, Pedoman untuk Tenaga Kesehatan (Guidelines for PMTCT program, for health provider). Kementerian Kesehatan RI. Jakarta

[4] Komisi Penanggulangan AIDS Nasional RI (National AIDS Commission). 2001. HIV/AIDS dan Infeksi Menular Seksual lainnya di Indonesia: Tantangan dan Peluang untuk Bertindak (HIV/AIDS dan STI in Indonesia: challenges and chances to undertake). KPA Nasional RI. Jakarta

[5] Ditjen PP\&PL Kementerian Kesehatan RI. Laporan situasi perkembangan HIV\&AIDS di Indonesia tahun 2013 (triwulan 3) (3rd semester of HIV\&AIDS cases progress situation report). Kementerian Kesehatan RI. Jakarta.

[6] Centers for Disease Control and Prevention. STDs and Pregnancy Fact Sheet. Retrieved from dari http://www.cdc.gov/std/pregnancy/stdfactpregnancy.htm on 11 Nopember 2014

[7] Kementerian Kesehatan Republik Indonesia. 2008. Infeksi Menular Seksual dan Infeksi Saluran Reproduksi pada Pelayanan Kesehatan Reproduksi Terpadu (STI and RTI on integrated reproductive health services). Retrieved from http://www.pppl.depkes.go.id/_asset/_download/I MS_dan_ISR_pada_Pelayanan_Kesehatan_Reprod uksi.pdf

[8] Centers for Disease Control and Prevention. STDs and Pregnancy Detailed Fact Sheet Retrieved from http://www.cdc.gov/std/pregnancy/stdfactpregnancy-detailed.htm, on 14 Mei 2016

Our research team is grateful for the opportunity provided by the National Institute of Health Research and Development, Center for Research and Development of Public Health Efforts, and the Scientific Development Board to carry out this research. We also thank Professor Dr. Syaiful Fahmi D, SpKK (K), dr. M. Alamsyah Aziz, SpOG (K), KIC., MKes, and the Health Development SubDirectorate for Pregnant Women and the HIV/AIDS and Sexually Transmitted Infectious Diseases Subdivision, POGI (Persatuan Obstetri dan Ginekologi Indonesia), who provided guidance during the preparation, implementation and writing of reports. We also thank Global Fund-AIDS Indonesia for funding the operational of the research.

\section{REFERENCES}

[1] Kementerian Kesehatan (Ministry of Health) Republic of Indonesia. 2015. Rapat Koordinasi Pengendalian Operasional Program: Kesehatan Dalam Rangka Sustainable Development Goals (Coordination meeting operational program control: Health in the scheme of SDG's). Dirjen Bina Gizi KIA, Kementerian Kesehatan RI. Jakarta

[9] American Pregnancy Association. HIV AIDS during pregnancy. Retrieved from http://americanpregnancy.org/pregnancycomplications/hiv-aids-during-pregnancy/).

[10] Pasaribu, L., S.L. Dyah, Sunarno, F. Rachmawati, N.I. Hariastuti, L.S. Nova, et al. 2016. Laporan penelitian prevalensi Infeksi Saluran Reproduksi dan HIV pada wanita hamil di beberapa kota di Indonesia, 2016-2017 (Unpublished report: study on RTI and HIV on pregnant women in some areas in Indonesia). Pusat Penelitian dan Pengembangan Upaya Kesehatan Masyarakat. Badan Penelitian dan Pengembangan Kesehatan. Kementerian Kesehatan RI. Jakarta.

[11] Kementerian Kesehatan Republik Indonesia. 2013. Buku Saku Pelayanan Kesehatan Ibu di layanan kesehatan dasar dan rujukan (Guidelines book of Mother's health service in primary and referral health centre). Kementerian Kesehatan Republik Indonesia. Jakarta.

[12] Travers, R. M.G. Wilson, S. Flicker, A. Guta, T. 
ISSN: 2503-2356.

Bereket, C. McKay . The greater involvement of people living with AIDS principle: theory versus practice in Ontario's HIV/AIDS community-based research sector., Pages 615-624 |, Published online: $24 \quad$ Jun 2008. https://doi.org/10.1080/09540120701661690

[13] Bharat, Shalini., Vaishali Sharma Mahendra. Meeting the Sexual and Reproductive Health Needs of People Living with HIV: Challenges for Health Care Providers. Pages 93-112| Published online: 23 May 2007. https://doi.org/10.1016/S09688080(07)29030-5

[14] Aryasih P.T. Peran Hambatan dan Tantangan Bidan di Layanan Antenatal Care (ANC) untuk Merujuk Ibu Hamil dalam Penemuan Kasus HIV di Kecamatan Serisit Kabupaten Buleleng Tahun 2011 (Midwives resistance and challenges in ANC to persuade pregnant women in HIV case detection in Serisit sub-district, Buleleng District, year 2011). Denpasar; Universitas Udayana; 2012 in Arniti, N.K., L.P. Wulandari, and D.N. Wirawan. Factor related to acceptance of HIV testing by pregnant mothers in health centres in Denpasar City. Public Health and Preventive Medicine Archive (PHPMA) 2014, Volume 2, Number 1: 63-69 E-ISSN: 25032356.

[15] Kementerian Kesehatan RI. Pedoman Nasional Pencegahan Penularan HIV dari Ibu ke Anak (PPIA) (National guidelines for PMTCT). Jakarta; 2012.

[16] Yuriati, P., O.W.K. Handayani, and E.F.Rustiana. Evaluasi pelaksanaan kegiatan Prevention Mother to Child Transmission (PMTCT) pada ibu hamil di Kota Tanjung Pinang (Evaluation of PMTCT activity accomplishment in pregnant women in Tanjung Pinang City). Public Health Perspective $\begin{array}{lllll}\text { Journal } & 1 & \text { (1) } \quad 2016 . & \mathrm{P} & 29-34 .\end{array}$ http://journal.unnes.ac.id/sju/index.php/phpj

[17]Legiati T., Z. Shaluhiyah, and A. Suryosaputro. Perilaku ibu hamil untuk tes HIV di Kelurahan Bandarharjo dan Tanjung Mas Kota Semarang (Pregnant women behavior for HIV testing in Bandarharjo village and Tanjung Mas village in Semarang City). Jurnal Promosi Kesehatan Indonesia Vol. 7 / No. 1 / Januari 2012

[18] Ernawati, A. Suryoputro, and Syamsulhuda B.M. Niat ibu hamil untuk test HIV di UPT (Unit Pelayanan Terpadu) Puskesmas Alun-alun Kabupaten Gresik (Pregnant women intention to HIV test in integrated health service in Puskesams Alun-alun, Gresik District). Jurnal Promosi Kesehatan Indonesia Volume 11/No.1/January 2016.

[19] Arniti, N.K., L.P. Wulandari, and D.N. Wirawan. Factor related to acceptance of HIV testing by pregnant mothers in health centres in Denpasar City. Public Health and Preventive Medicine Archive (PHPMA) 2014, Volume 2, Number 1: 63-69 E-
20] Fitriani, I. Sofiyanti, and Y. Siswanto. 2016. Artikel Skripsi: Faktor-faktor yang berhubungan dengan tes HIV pada ibu hamil di Puskesmas Bergas, Kabupaten Semarang Tahun 2016 (Thesis paper: factors correlated with HIV test among pregnant women in Puskesmas Bergas, Semarang District, year 2016). Program Studi D-IV Kebidanan, Sekolah Tinggi Kesehatan Ngudi Waluyo. Ungaran.

[21] Mulyanti, S. 2012. Skripsi: factor-faktor yang berkontribusi pada perilaku ibu hamil trimester 2 dan 3 dalam pemeriksaan HIV di empat Puskesmas Kota Pontianak (Thesis: factors that contribute to 2nd and 3rd trimester pregnant women behavior on HIV testing in 4 Puskesmas in Pontianak City). Fakultas Kesehatan Masyarakat, Program Kebidanan Komunitas, Universitas Indonesia. Kota Depok.

[22] Departemen Kesehatan Republik Indonesia. 2008. Modul Pelatihan Pencegahan Penularan dari Ibu ke Bayi (Training for PMTCT prevention module). Jakarta. In Ernawati, A. Suryoputro, and Syamsulhuda B.M. Niat ibu hamil untuk test HIV di UPT (Unit Pelayanan Terpadu) Puskesmas Alunalun Kabupaten Gresik. Jurnal Promosi Kesehatan Indonesia Volume 11/No.1/January 2016.

[23] Kementerian Kesehatan RI. 2013. Lampiran Peraturan Menteri Kesehatan No.51 Tahun 2013 tentang pedoman Pencegahan Penularan HIV dari Ibu ke Anak (Attachment to the Regulation of the Minister of Health No.51, 2013 about guidelines of PMTCT). Kementerian Kesehatan RI. Jakarta.

[24] Centers for Disease Control and Prevention. STDs and Pregnancy Detailed Fact Sheet Retrieved from http://www.cdc.gov/std/pregnancy/stdfactpregnancy-detailed.htm, on 14 Mei 2016. 